\title{
Serotonin transporter gene (5-HTT) polymorphism and major depressive disorder in patients in Bogotá, Colombia
}

\author{
Isabel Pérez-Olmos ${ }^{1}$, Delia Bustamante ${ }^{2}$, Milcíades Ibáñez-Pinilla ${ }^{1}$ \\ 1 Centro de Investigación, Escuela de Medicina y Ciencias de la Salud, Universidad del Rosario, Bogotá, D.C., \\ Colombia \\ 2 Programa de Especialización en Psiquiatría, Universidad del Rosario, Bogotá, D.C., Colombia
}

Introduction: The 5-HTT short allele has been controversially associated with an increased risk of major depressive disorder.

Objective: To determine the association of 5-HTT short allele with major depression in Bogotá, Colombia. Materials and methods: We carried out a study of cases $(n=68)$ matched 1:1 with controls by gender and age ( \pm 5 years). Major depression was diagnosed using the Mini-International Neuropsychiatric Interview, and 5-HTT polymorphism using PCR.

Results: Females were predominant (82.4\%). The S (short) allele predominated in cases compared with controls (S: $72.1 \%$ vs. 63.2 ; L (long): $27.9 \%$ vs. $36.8 \%$ ), and the SL genotype was more frequent in cases (SL: $45.6 \%$ vs. $36.8 \%$; LL: $27.9 \%$ vs. $36.8 \%$; SS: $26.5 \%$ vs. $26.5 \%$ ), although not significantly. There were significant differences in those under age 37, with a predominance of the $S$ allele in cases $(p=0.038 ; O R=2.75 ; 95 \% \mathrm{Cl}: 0.88-8.64)$. Multivariate analysis, adjusted for comorbid anxiety disorders, showed a significant association of major depression with the SL genotype $(p=0.049 ; 0 R=3.20 ; 95 \%$ $\mathrm{Cl}$ : 1.00-10.23); the $\mathrm{S}$ allele was close to statistical significance $(\mathrm{p}=0.063$; $\mathrm{OR}=2.94 ; 95 \% \mathrm{Cl}$ : $0.94-$ $9.13)$, and it was statistically significant in cases under 37 years of age $(p=0.026 ; O R=10.79 ; 95 \% \mathrm{Cl}$ : 1.32-80.36).

Conclusions: The SL genotype was associated with major depressive disorder in patients of all ages. The $S$ allele was significantly associated with major depressive disorder in patients under age 37, adjusted for comorbid anxiety disorders.

Key words: serotonin; polymorphism, genetic; depressive disorder, major; anxiety disorders; suicide; risk; comorbidity.

doi: http://dx.doi.org/10.7705/biomedica.v36i3.3014

\section{Polimorfismo del gen del transportador de serotonina (5-HTT) y trastorno de depresión mayor en pacientes en Bogotá, Colombia}

Introducción. El polimorfismo 5-HTT se ha asociado con el trastorno de depresión mayor, aunque el planteamiento ha generado controversia.

Objetivo. Determinar la asociación del polimorfismo 5-HTT con la depresión mayor en Bogotá, Colombia. Materiales y métodos. Se hizo un estudio de casos y controles pareado por sexo y edad ( \pm 5 años), con una razón de uno a uno (68:68). El trastorno de depresión mayor se diagnosticó con el cuestionario Mini-International Neuropsychiatric Interview, y, el polimorfismo 5-HTT, mediante reacción en cadena de la polimerasa (PCR).

Resultados. Las mujeres predominaron entre los participantes (82,4\%). El alelo corto (short, S) predominó en los casos comparados con los controles (S: 72,1\% Vs. 63,2; L (long): $27,9 \%$ Vs. $36,8 \%$ ), y el genotipo SL fue más frecuente en los casos (SL: 45,6 \% Vs. 36,8 \%; LL: 27,9 \% Vs. $36,8 \%$; SS: $26,5 \%$ Vs. $26,5 \%$ ), aunque no significativamente. Hubo diferencias significativas en menores de 37 años, con predominio del alelo $S$ en los casos $\left(p=0,0384\right.$; odds ratio - OR=2,75; $I C_{95 \%}$ : $0,88-8,64)$. El análisis multivariado ajustado por trastornos concomitantes de ansiedad mostró una asociación significativa de la depresión mayor con el genotipo $S L\left(p=0,049\right.$; OR=3,20; IC ${ }_{95 \%} 1,003$ $10,233)$; el alelo $S$ estuvo cerca de la significación estadística $\left(p=0,063 ; O R=2,94 ; I_{95 \%} 0,94-9,13\right)$, y fue estadísticamente significativo en los casos de menores de 37 años $\left(p=0,026 ; O R=10,79 ; I_{95 \%}\right.$ $1,32-80,36)$.

\section{Author's contributions:}

All authors significantly contributed to the study design, the research protocol, the search of bibliography on the topic, data base quality, statistical analysis, and to the drafting of the manuscript. 
Conclusiones. El genotipo SL se asoció con el trastorno de depresión mayor en pacientes de todas las edades. El alelo S se asoció significativamente con el trastorno de depresión mayor en pacientes menores de 37 años al ajustar por trastornos concomitantes de ansiedad.

Palabras clave: serotonina, polimorfismo genético, trastorno depresivo mayor, trastornos de ansiedad, suicidio, riesgo, comorbilidad.

doi: http://dx.doi.org/10.7705/biomedica.v36i3.3014

The major depressive disorder is a globally significant public health problem. It is highly prevalent, chronic and incapacitating, it occurs frequently with comorbidities, and results in loss of productivity, increased mortality rates, and, additionally, its medical treatment is very expensive for countries.

Lifetime prevalence of major depression episodes in the general population varies considerably among countries, although in most it is $8-12 \%$; in some, like Japan, it is $3 \%$, and in others, like the United States, it is $16.9 \%$ (1). In Colombia, the last National Mental Health Survey conducted in 2003 showed a lifetime prevalence of mood disorders of $15.0 \%$, with major depressive disorder being the most frequent (12.1\%) (2).

According to the World Health Organization (WHO), the major depressive disorder is one of the most common causes of disability and burden of disease worldwide $(3,4)$; it is projected that it will be in the second place in 2020, and in the first place in 2030 (4). The major depressive disorder is one of the five main factors associated with absenteeism and decreased work capacity (5). Added to the medical treatment costs are those caused by the loss of productive capacity and decreased work performance (6).

In Colombia, the major depressive disorder is the first cause of disease burden in women, and the second in men, after cardiovascular diseases, especially in the most productive ages (7).

The major depressive disorder is a complex, multifactorial disease, with very heterogeneous clinical manifestations, whose etiological and pathological mechanisms have not been completely elucidated. It is considered inheritable, of polygenic origin, with clinical manifestations resulting from genetic-

\footnotetext{
Corresponding author:

Isabel Pérez-Olmos, Centro de Investigación, Escuela de Medicina y Ciencias de la Salud, Universidad del Rosario, Carrera $24 N^{\circ}$ 63C-69, Bogotá, D.C., Colombia Telefax: (571) 297 0200, extension 3426 isabel.perez@urosario.edu.co
}

Received: 03/08/15; accepted: 06/01/16 environmental interactions (8). The hereditability of the major depressive disorder has been estimated at $37 \%$, with a range of $31-42 \%(9)$. The characteristics of the familial pattern include early appearance of symptoms, chronic course, and frequent recurrences (10). Having a first-degree relative with major depressive disorder increases the risk of developing it by two to three times, compared with the risk of the general population (11). In addition, some authors have proposed a greater hereditability of the major depressive disorder in women than in men (12).

One of the most noted factors in the biological etiology and pathological pathways of the major depressive disorder has been the serotonin transporter, 5-HTT (SERT); many current antidepressant medications exert their effect here. The transporter regulates the concentration of serotonin in the synaptic space, being essential for mood regulation (13).

The gene that codes the serotonin transporter protein in the presynaptic neurons is located on the long arm of human chromosome 17 (17q1112). The insertion/deletion (in/del) polymorphism of $44 \mathrm{bp}$ in the transcription control region has been one of the most studied in the 5-HTT gene. This polymorphism results in two allele variations with different sizes and activity: A long allele (L) with 16 repetitions, and a short one (S), with 14. Each individual may be a carrier of one of the two homozygotic combinations, LL, SS, or a heterozygotic combination, SL. In human cells, the $S$ allele reduces the activity of the transporter, which decreases the levels of messenger RNA and the expression of presynaptic 5-HTT (14-16). It has been found that the LL cells can produce messenger RNA levels for 5-HTT 1.4 to 1.7 times greater than those of the short allele (14). In turn, the LL variant of 5-HTT is capable of removing 1.9 to 2.2 times more serotonin from the synaptic cleft than the SS or SL variants (17). The short allele of this polymorphism produces lower levels of transporter transcription, which has associated it with a greater risk of bipolar and unipolar mood disorders $(18,19)$. 
The association of this mutation with major depressive disorder has been one of the most researched, reporting a statistically significant association. Haenisch, et al., found a significant association between the short (S) allele and major depressive disorder (19). However, the results have been controversial, since they have not coincided among researchers. Some authors have found this statistical association between the 5-HTT (in/del O indel) polymorphism and mood disorders, particularly major depression, shown additionally in meta-analyses such as that of López-León (19-21). Anguelova, et al., also found a strong association between the 5HTT gene in/del polymorphism and the risk of suicide (22), and other authors demonstrated the association between this polymorphism and bipolar affective disorder $(20,23)$. However, in Western European descendants, Hoehe, et al., found no significant differences in the genotypic or allele frequencies of the 5-HTT polymorphism in 36 patients with major depression, 79 with bipolar I disorder, and 294 controls (24). In Germany, Minov, et al., found a greater proportion of SS homozygotes in 173 cases of major depression (23.1\%) compared with 121 controls $(14.0 \%)$, although the difference was not statistically significant (25). Medlewicz, et al., in a large, multi-centric study in Europe, found no significant differences in 539 cases of major unipolar depression and 821 controls regarding the effect of this polymorphism on the susceptibility to major depression; in this study, the authors discarded the possibility of negative results being attributable to a lack of statistical power (26). Serretti, in turn, did not find an association between 5HTT polymorphism and severe psychotic disorders in Italy (27).

Three studies have been published in Colombia on the association of 5-HTT polymorphism with mood disorders. Two of them have involved bipolar disorder cases (BPD I): one in Medellín with participants from all the department of Antioquia (28), and the other, in the Colombian coffeegrowing region (departments of Risaralda and Quindío) (29).

Only one of the Colombian studies involved major depressive disorder cases (30). These three studies found no statistically significant association between 5-HTT polymorphism and the evaluated mood disorder. However, this last study on major depressive disorder showed that the absence of the $S$ allele conferred a protective tendency against the major depressive disorder, although it did not achieve statistical significance.
The present study evaluated the association between the in/del polymorphism of the serotonin transporter gene (5-HTT) and major depressive disorder in a group of Colombian patients residing in Bogotá, Colombia.

\section{Materials and methods}

This was a case-control study paired by sex and age ( \pm 5 years).

\section{Recruitment process}

Cases and controls were recruited between September, 2011, and July, 2013, in outpatient departments and hospitalization services in private psychiatric institutions and public hospitals in Bogotá, especially in those where Universidad del Rosario's psychiatry residents and collaborating psychiatrists carried out their practice. Patients and controls assessed with the Mini-International Neuropsychiatric Interview (MINI), were screened for major depressive disorder and other axis I disorders.

\section{Selection criteria}

The inclusion of participants was based on the fulfillment of the diagnostic criteria for major depressive disorder established in the American Psychiatric Association's Diagnostic and Statistical Manual of Mental Disorders (DSM-IV-TR). The potential cases were patients diagnosed as major depressive disorder cases in the psychiatric services in Bogotá. Exclusion criteria for cases included those patients who had a major depressive episode in the context of a bipolar mood disorder, mental retardation, or pervasive developmental disorder; patients with psychotic symptoms characteristic of schizophrenia or other psychoses, or those who did not want to participate in the study. After evaluating the inclusion and exclusion criteria, and signing the informed consent, 87 cases that fulfilled the selection criteria were initially pre-selected.

We selected the controls from hospital and university academic and administrative personnel after inviting adult volunteers from all departments of the institutions collaborating in the study to participate. An individual appointment was set up to evaluate the inclusion and exclusion criteria and for participants to sign the informed consent, until the required number of controls was recruited among those who did not fulfill the diagnostic criteria for major depressive disorder using the structured MINI interview.

The exclusion criteria for controls were the following: those who had a bipolar affective disorder, potential controls with a family history of major depressive 
disorder, or controls using illegal psychoactive substances, due to the known association between these disorders and mood disorders. We selected 131 controls from the above-mentioned institutions. Participants were between 18 and 79 years old, residing in Bogotá, who agreed to participate in the study by signing the informed consent.

\section{Data collection and study variables}

The data collection instrument included demographic variables (age, educational level, gender, marital status, socioeconomic status), as well as the body mass index (BMI), co-morbidities, use of psychoactive substances, smoking and/or alcohol consumption, other axis I diagnoses from the DSM-IV-TR, prior hospitalizations in mental health units, prior treatment with anti-depressants, family history of mental illness, characteristics of the major depressive illness (relapses, presence of melancholic symptoms), suicidal behavior, and the results on the presence of 5-HTT gene polymorphism.

\section{Genetic analysis}

Blood samples were taken for genotyping. For both cases and controls, subjects on whom genotyping could not be performed were excluded. After applying the inclusion and exclusion criteria, and the pairing techniques according to sex and age variables to pre-selected cases and controls, the final group included 136 participants, 68 cases and 68 controls, paired by sex and age ( \pm 5 years).

Genetic analysis was performed in the Genetics Department of the Universidad del Rosario as described below. The peripheral blood samples underwent DNA extraction using conventional salting out techniques. A polymerase chain reaction (PCR) was performed with specific primers designed for analyzing 5-HTT polymorphism. All the amplified products were analyzed in agarose gels stained with $1.2 \%$ ethidium bromide. For each PCR run, a negative control was used, which established the absence of contamination. Genotypification was performed by two geneticists from the Universidad del Rosario Genetics Department, with independent evaluations. No analytical discrepancies or Mendelian errors were seen. The analyzed alleles pertained to insertion (419 bp) or deletion (375 bp) of $44 \mathrm{bp}$.

\section{Statistical analysis}

The information obtained from the cases and controls was transcribed to a data base (Microsoft Office Excel, version 2010). In order to guarantee the quality of the information and avoid classification biases, data base cleansing was performed with verification by two observers. Finally, transcription errors were evaluated with simple frequencies and logical cross-checks between variables. Processing was done on Epi-Info, version 7.0; STATA ${ }^{\circledR}$ 11.0, and SPSS ${ }^{\circledR}$, version 20.0.

We described independent variables and evaluated the normality of the quantitative variables using the Shapiro-Wilk test with a $10 \%$ significance level $(p<0.10)$. For continuous and discrete quantitative variables with an approximately normal distribution, the arithmetic mean was used as the measure of central tendency, and standard deviation as the measure of dispersion. For quantitative variables with a non-normal distribution, we used the median and the range. Categorical variables were displayed in tables with absolute and relative frequencies expressed in percentages.

In the bivariate analysis, we evaluated the probability of the presence of associated qualitative factors with a dichotomous variable (exposure) and major depression. We used $2 \times 2$ tables to obtain the odds ratio (OR) and its respective $95 \%$ confidence interval, with estimations of paired maximumlikelihood, McNemar's chi squared test for asymptotic association, and the Mantel-Haenszel test without correction and with continuity correction (expected values $\geq 5$ ), or Fisher's exact test, or the mid-p test, for related samples (expected values $<5$ ).

In factors associated with a multinomial variable, we used the conditional logistic regression for paired cases and controls with a 1:1 ratio through contrasts for indicator variables, taking one of the $\mathrm{k}$ categories as a base and creating k-I indicator variables. Factors with a quantitative variable were also evaluated using conditional logistic regression. The interaction or modification of the factors' effects was evaluated in the conditional logistic regression model. Previously, we evaluated the assumption of multi-colinearity between the independent variables.

We evaluated the association between 5-HTT gene polymorphism and major depressive disorder adjusting for confounding variables, and using the conditional logistic regression model, as well as the presence of Hardy-Weinberg equilibrium by Pearson's chi- squared test. The level of significance used in the bivariate and multivariate analysis was $5 \%(p<0.05)$.

We performed a post hoc power analysis. Exploring the association of the 5-HTT polymorphism and major depression disorder in a multivariate analysis 
of 68 matched cases and controls of all ages, the SL genotype was present in $36.8 \%$ of controls and in $45.6 \%$ of cases, yielding an OR of 3.2 with a $95 \%$ confidence level $(p=0.049)$ and a statistical power of $90.6 \%$.

We analyzed the association of the 5-HTT polymorphism and major depression disorder in 35 matched young cases (36 years old or younger), and found that the $\mathrm{S}$ allele was present in $51.5 \%$ of controls and in $74 \%$ of cases, yielding an OR of 2.75 with a $95 \%$ confidence level; however, the statistical power was $49.1 \%$, probably because the younger cases were a small sample of 35 cases and 33 controls.

The project was approved by the Research Ethics Committee of the Universidad del Rosario, and classified as a minimal risk study, since a blood sample no greater than $10 \mathrm{ml}$ was taken from participants. All patients and controls signed an informed consent for the use of their DNA samples. The project adhered to the national ethical norms as stated in Resolution 8430 of 1993, and the international ethical norms for human research.

\section{Results}

The study group included 136 individuals: 68 cases and 68 controls. According to the results of the structured DSM-IV-TR MINI interview, the cases fulfilled the criteria for major depressive disorder; $70.6 \%$ of these patients had melancholic symptoms, and $64.2 \%$ had some degree of suicide risk; the suicide risk was classified as slight (32.8\%), severe $(25.4 \%)$, and moderate $(6.0 \%) ; 47.1 \%(n=32)$ of participants had received prior antidepressant therapy, and $19.1 \%$ of them $(n=13)$, more than one treatment. The most prescribed medications were fluoxetine $(40 \%)$, sertraline $(24 \%)$ and amitriptyline $(9 \%)$.

In the general group there was a 4.7:1 female-male ratio, a mean age of $37.7 \pm 11.1037 .7 \pm 11.1$ years and a median of 36 years that was used as a cutoff point for exploring the association of the 5-HTT gene polymorphism and the major depressive disorder risk. Although most participants were single $(42.8 \%), 43.4 \%$ reported having a stable partner; $25.7 \%$ of participants had professional training; $20.6 \%$ had completed graduate studies, and $1.5 \%$ had not attended school. As for their socio-economic status, most participants belonged to middle levels: $39.7 \%$ to level 3 (out of 6 ) and $25.7 \%$ to level 2 (out of 6 ). There were no significant differences in demographic variables between cases and controls (table 1 ).
Table 1. Socio-demographic variables, 5-HTT polymorphism, and major depressive disorder. Paired case-control study. Bogotá, Colombia, 2013.

\begin{tabular}{|c|c|c|c|c|c|}
\hline \multirow[t]{2}{*}{ Variable } & \multicolumn{2}{|c|}{ Cases } & \multicolumn{2}{|c|}{ Controls } & \multirow[t]{2}{*}{$\mathbf{p}$} \\
\hline & $\mathbf{n}$ & $\%$ & $\mathbf{n}$ & $\%$ & \\
\hline \multicolumn{6}{|l|}{ Age group (years) } \\
\hline$\leq 36$ & 35 & 51.5 & 33 & 48.5 & 0.732 \\
\hline$\geq 37$ & 33 & 48.5 & 35 & 51.5 & \\
\hline Total & 68 & 100 & 68 & 100 & \\
\hline \multicolumn{6}{|l|}{ Sex } \\
\hline Women & 56 & 82.4 & 56 & 82.4 & 1.000 \\
\hline Men & 12 & 17.6 & 12 & 17.6 & \\
\hline Total & 68 & 100 & 68 & 100 & \\
\hline \multicolumn{6}{|l|}{ Marital status } \\
\hline Married or stable partner & 39 & 57.4 & 39 & 57.4 & 1.000 \\
\hline Single or separated & 29 & 42.6 & 29 & 42.6 & \\
\hline Total & 68 & 100 & 68 & 100 & \\
\hline \multicolumn{6}{|l|}{ Economic status } \\
\hline Low (1 \& 2) & 20 & 29.4 & 16 & 23.5 & 0.690 \\
\hline Middle (3 \& 4) & 41 & 60.3 & 43 & 63.2 & \\
\hline High (5 \& 6) & 7 & 10.3 & 9 & 13.2 & \\
\hline Total & 68 & 100 & 68 & 100 & \\
\hline \multicolumn{6}{|l|}{ Educational level } \\
\hline High & 30 & 44.1 & 33 & 48.5 & 0.112 \\
\hline Middle & 22 & 32.4 & 28 & 41.2 & \\
\hline Low & 16 & 23.5 & 7 & 10.3 & \\
\hline Total & 68 & 100 & 68 & 100 & \\
\hline
\end{tabular}

\section{Clinical characteristics and history}

The average body mass index (BMI) of cases was $24.7 \pm 4.8 \bigcirc 24.7 \pm 4.8 \mathrm{~kg} / \mathrm{m}^{2}(\mathrm{med}=24)$, and of controls, $23.9 \pm 3.1 \mathrm{~kg} / \mathrm{m}^{2}$ (med=24), without significant differences ( $p=0.576$, Wilcoxon's test). The prevalence of current smoking was significantly greater in cases than in controls $(23.5 \%$ vs. $2.9 \%$; $\mathrm{p}=0.0003 ; \mathrm{OR}=15 ; 95 \% \mathrm{Cl}: 1.98-113.56)$; there was no association between alcohol use and major depression. In the evaluation of family and personal history there was a greater frequency of prior depression and antidepressant therapy in cases than in controls ( $p<0.001$, McNemar's test) (table 2).

\section{Psychiatric comorbidities}

The comorbidities found to be significantly associated with major depressive disorder among cases were anxiety disorder sometime in their lifetime, and generalized anxiety disorder; the other comorbidities did not show a significant association. The severity of suicide risk was greater in cases than in controls (slight: $32.8 \%$ vs. $4.4 \%$, moderate: $6.0 \%$ vs. $0 \%$, and severe: $25.4 \%$ vs. $0 \%$ ) ( $<<0.001$; $\mathrm{OR}=42.0 ; 95 \% \mathrm{Cl}: 5.78-305.16$ ) (table 3).

Table 4 shows the distribution of the genotype and allele frequencies of the 5-HTT gene in the study sample. The study population was in Hardy- 
Weinberg equilibrium ( $p>0.05)$. The SL genotype and $S$ allele group frequency was greater in cases than in controls, although with no significant difference; the frequency of the $S$ allele was significantly greater in the group of cases under the age of 37 .

\section{Multivariate analysis}

In the conditional logistic regression model, the SL heterozygote of the 5-HTT gene polymorphism was found to be significantly associated with major depression after adjusting for co-morbid anxiety disorders (generalized anxiety and anxiety disorder at least once in their lifetime). The severity of the suicide risk was found to be very significantly associated with major depression, and was ultimately excluded from the model due to its high colinearity with generalized anxiety disorder $(p=0.018 ; O R=5.15 ; 95 \% \mathrm{Cl}: 1.26-20.96)$ and with anxiety disorder at least once in their lifetime $(p=0.003$; OR=3.89; 95\% Cl: 1.53-9.88).

In the conditional logistic regression model, the $S$ allele was found to be borderline significant for major depression $(p=0.063$; OR=2.94; $95 \% \mathrm{Cl}$ : 0.94-9.13) after adjusting for the same variables (table 5).

Stratifying by age group, in those under 37 years, the $S$ allele showed a significant association with major depression after adjusting for comorbid anxiety disorders $(p=0.026$; $O R=10.79 ; 95 \% \mathrm{Cl}$ : 1.32-80.36).

\section{Discussion}

The socio-demographic characteristics of the participants in this study were similar to those reported in other parts of the world (31). Major depressive disorder is more frequent in women, the unemployed, and single or separated individuals, irrespective of socio-economic status. Likewise, the frequency of use of psychoactive substances did not differ greatly from that found previously in the national population, except for a higher frequency of smoking in the major depressive disorder cases in this study (2).

Our results showed a distribution of the 5-HTT gene polymorphism similar to that of three other

Table 2. Clinical and familial variables, 5-HTT polymorphism and major depressive disorder. Paired case-control study. Bogotá, Colombia, 2013

\begin{tabular}{|c|c|c|c|c|c|c|}
\hline \multirow[t]{2}{*}{ Variable } & \multicolumn{2}{|c|}{ MDD Cases } & \multicolumn{2}{|c|}{ Controls } & \multirow[t]{2}{*}{$p$ value } & \multirow[t]{2}{*}{ OR $(95 \% \mathrm{Cl})$} \\
\hline & $\mathbf{n}$ & $\%$ & $\mathbf{n}$ & $\%$ & & \\
\hline PSC consumption & 3 & 4.4 & 0 & 0 & NA & \\
\hline Lifetime smoking & 19 & 27.9 & 10 & 14.7 & 0.046 & $2.29 \quad(2.29-5.56)$ \\
\hline Current alcohol consumption & 17 & 25.0 & 25 & 36.8 & 0.103 & $0.50 \quad(0.214-1.168)$ \\
\hline Psychiatric hospitalization & 11 & 16.2 & 0 & 0 & NA & \\
\hline Previous antidepressant treatment & 32 & 47.1 & 1 & 1.5 & $<0.001$ & \\
\hline More than one antidepressant treatment & 13 & 19.1 & 0 & 0 & NA & \\
\hline MDD in family & 26 & 38.2 & 3 & 4.4 & $<0.001$ & $12.50 \quad(2.961-52.774)$ \\
\hline BPD in family & 3 & 4.4 & 4 & 5.9 & 0.500 & $0.750(0.168-3.351)$ \\
\hline Suicide in family & 5 & 7.4 & 0 & 0 & NA & \\
\hline Schizophrenia in family & 4 & 5.9 & 3 & 4.4 & 0.500 & $1.33 \quad(0.298-5.958)$ \\
\hline
\end{tabular}

PSC: Psychoactive substance consumption; BPD: Bipolar disorder; MDD: Major depression disorder; NA: Does not apply

Table 3. Psychiatric diagnosis and comorbidity, 5-HTT polymorphism and major depressive disorder (MDD). Paired case-control study. Bogotá, Colombia, 2013

\begin{tabular}{|c|c|c|c|c|c|c|c|}
\hline & & \multicolumn{2}{|c|}{ MDD cases } & \multicolumn{2}{|c|}{ Controls } & \multirow[t]{2}{*}{$\mathbf{p}$} & \multirow{2}{*}{$\begin{array}{c}\text { OR } \\
(95 \% \mathrm{Cl})\end{array}$} \\
\hline & & $\mathbf{n}$ & $\%$ & $\mathbf{n}$ & $\%$ & & \\
\hline Lifetime anxiety disorder & + & 21 & 30.9 & 2 & 2.9 & $<0.001$ & $20.0 \quad(2.684-149.028)$ \\
\hline Agoraphobia & + & 7 & 10.3 & 0 & 0 & NA & \\
\hline Social phobia & + & 5 & 7.4 & 4 & 5.9 & 0.500 & $1.25(0.336-4.655)$ \\
\hline Obssessive-compulsive disorder & + & 4 & 5.9 & 3 & 4,4 & 0.500 & $1.33(0.298-5.958)$ \\
\hline Anorexia & + & 2 & 2.9 & 0 & 0 & NA & \\
\hline Bulimia & + & 3 & 4.4 & 2 & 2.9 & 0.500 & $1.50(0.251-8.977)$ \\
\hline Generalized anxiety disorder & + & 9 & 13.2 & 1 & 1.5 & 0.011 & $9.00(1.140-71.040)$ \\
\hline
\end{tabular}

NA: Does not apply 
Table 4. 5-HTT polymorphism and major depressive disorder. Genotype and allele frequency by age group. Paired case-control study. Bogotá, Colombia, 2013

\begin{tabular}{|c|c|c|c|c|c|c|c|}
\hline \multirow{2}{*}{$\begin{array}{l}\text { Age (years) } \\
\text { All ages }\end{array}$} & \multirow{2}{*}{$\begin{array}{c}\begin{array}{c}5-\mathrm{HTT} \\
\text { polymorphism }\end{array} \\
\text { Genotype }\end{array}$} & \multicolumn{2}{|c|}{ Cases } & \multicolumn{2}{|c|}{ Controls } & \multirow[t]{2}{*}{$\mathbf{p}$} & \multirow[t]{2}{*}{ OR (95\% Cl) } \\
\hline & & $\mathbf{n}$ & $\%$ & $\mathbf{n}$ & $\%$ & & \\
\hline & LL & 19 & 28 & 25 & 36.8 & & 1.000 \\
\hline & SS & 18 & 27 & 18 & 26.5 & 0.514 & $1.38(0.524-3.629)$ \\
\hline & SL & 31 & 46 & 25 & 36.8 & 0.237 & $1.62(0.729-3.596)$ \\
\hline & Alleles & & & & & & \\
\hline & $\mathrm{S}$ & 49 & 72 & 43 & 63.2 & 0.173 & $1.54(0.724-3.299)$ \\
\hline & L & 19 & 28 & 25 & 36.8 & & 1.000 \\
\hline \multirow[t]{4}{*}{$\leq 36$} & Genotype & & & & & & \\
\hline & LL & 9 & 26 & 16 & 48.5 & & 1.000 \\
\hline & SS & 10 & 29 & 9 & 27.3 & 0.299 & $2.32(0.475-1.306)$ \\
\hline & SL & 16 & 46 & 8 & 24.2 & 0.079 & $2.83(0.887-9.011)$ \\
\hline \multirow[t]{8}{*}{$\geq 37$} & Alleles & & & & & & \\
\hline & $S$ & 26 & 74 & 17 & 51.5 & 0.038 & $2.75(0.876-8.637)$ \\
\hline & $\mathrm{L}$ & 9 & 26 & 16 & 48.5 & & \\
\hline & LL & 10 & 30 & 9 & 25.7 & & 1.000 \\
\hline & SS & 8 & 24 & 9 & 25.7 & 0.731 & $0.79(0.203-3.061)$ \\
\hline & SL & 15 & 46 & 17 & 48.6 & 0.838 & $0.87(0.237-3.219)$ \\
\hline & S & 23 & 70 & 26 & 74.3 & 0.500 & $0.83(0.254-2.730)$ \\
\hline & $\mathrm{L}$ & 10 & 30 & 9 & 25.7 & & \\
\hline
\end{tabular}

Table 5. Multivariate analysis of association of the 5-HTT polymorphism and major depression disorder. Paired casecontrol study. Bogotá, Colombia, 2013

\begin{tabular}{lrrl}
\hline Variable & p & \multicolumn{1}{c}{ OR } & OR 95 \% Cl \\
\hline Generalized anxiety disorder & 0.110 & 6.38 & $0.656-62.132$ \\
Lifetime anxiety disorder & 0.003 & 23.80 & $2.849-198.763$ \\
SS genotype & 0.288 & 2.14 & $0.527-8.672$ \\
SL genotype & 0.049 & 3.20 & $1.003-10.238$ \\
LL genotype & 1.000 & & \\
\hline
\end{tabular}

studies carried out in Colombian population (2830 ). The genotype frequencies of Colombian cases and controls including those from the present study are summarized in table 6 .

In both Colombian studies on borderline personality disorder 1 (BPD1) cases, a greater frequency of the SS genotype and $S$ allele was found in the evaluated population, similar to what was found in a Spanish population compared with European populations. The study by Ospina-Duque, et al., found an excess of the $S$ allele, $53 \%$ in controls from Antioquia. Although Ospina-Duque did not find an association of 5-HTT polymorphism with BPD 1, they did find a greater frequency of some clinical characteristics of BPD 1 in the presence of the $S$ allele: Greater clinical severity, greater frequency of manic episodes, younger age at onset of the disorder, and psychotic symptoms. The psychotic symptoms associated with the $S$ allele reached statistical significance when the Ospina-Duque group combined them with data reported by Ho, et al., thereby confirming the hypothesis that the $S$ allele acts as a modifier of the BPD 1 phenotype $(28,32)$.

On the other hand, the BPD1 cases evaluated by Rengifo in the Colombian coffee growing region showed a non-statistically significant increase of the LL genotype in cases compared to controls (22.6\% vs. $13.3 \%)$. When separated by sex, the LL genotype was more frequent in women with BPD 1 than in control women $(22.7 \%$ vs. $11.6 \%)$, although the frequency of this genotype was similar in women and men with BPD 1 (22.7\% vs. $22.2 \%)$. The distribution of the SS genotype was similar in cases of BPD 1 and controls in Rengifo's study $(33.1 \%$ vs. $31.7 \%)$, and similar to the distribution found in cases of MDD and controls in our study (26.5\% vs. $26.5 \%$ ) (29).

The distribution of 5-HTT genotypes in Escobar, et al.'s major depressive disorder study in a population from Caldas department in Colombia, was similar to that in our study (30). Regarding the risk of major depression, Escobar's study showed a tendency to major depression risk in the presence of the $S$ allele, and, therefore, protection in its absence, although according to our findings, this tendency did not reach statistical significance (30).

We found a high comorbidity of major depression and anxiety disorders, particularly anxiety disorders at least once in participants' lifetime. The literature 
Table 6. 5-HTT gene polymorphism frequency in Colombian populations

\begin{tabular}{|c|c|c|c|c|c|c|}
\hline & \multicolumn{3}{|c|}{$\begin{array}{c}(28) \\
n(\%)\end{array}$} & \multicolumn{3}{|c|}{$\begin{array}{l}(29) \\
\text { n (\%) }\end{array}$} \\
\hline & $\begin{array}{c}\text { BPD } \\
103(47.9)\end{array}$ & $\begin{array}{l}\text { Controls } \\
112(52.1)\end{array}$ & $\begin{array}{c}\text { Total } \\
(n=215)\end{array}$ & $\begin{array}{c}\text { BPD I } \\
133(52.6)\end{array}$ & $\begin{array}{l}\text { Controls } \\
120(47.4)\end{array}$ & $\begin{array}{c}\text { Total } \\
(n=253)\end{array}$ \\
\hline SS & 27 (26.2) & $29(25.8)$ & $56(26)$ & $44(33.1)$ & 38 (31.7) & $82(32.1)$ \\
\hline LS & 47 (46.5) & $61(54.4)$ & $108(50.2)$ & $59(44.4)$ & $66(55)$ & $125(49.4)$ \\
\hline \multirow[t]{3}{*}{ LL } & $29(28.1)$ & $22(19.6)$ & $51(23.7)$ & 30 (22.6) & 16 (13.3) & $46(18.1)$ \\
\hline & \multicolumn{3}{|c|}{$\begin{array}{c}(30) \\
\text { n (\%) }\end{array}$} & \multicolumn{3}{|c|}{$\begin{array}{c}\text { This article } \\
\text { n (\%) }\end{array}$} \\
\hline & MDD 59 (50) & $\begin{array}{c}\text { Controls } \\
59(50)\end{array}$ & Total $(n=118)$ & $\begin{array}{c}\text { MDD } \\
68(50)\end{array}$ & $\begin{array}{c}\text { Controls } 68 \\
(50)\end{array}$ & Total $(n=136)$ \\
\hline SS & $18(30.5)$ & $11(18.7)$ & $29(24.6)$ & $18(26.5)$ & $18(26.5)$ & $36(26.5)$ \\
\hline LS & 27 (45.8) & $30(50.8)$ & 57 (48.3) & $31(45.6)$ & $25(36.8)$ & $56(41.2)$ \\
\hline LL & $14(23.7)$ & $18(30.5)$ & $32(27.1)$ & 19 (27.9) & $25(36.8)$ & $44(32.4)$ \\
\hline
\end{tabular}

BPD: Bipolar disorder cases; BPD 1: Bipolar disorder 1 cases; MDD: Major depression disorder cases

has shown an association between anxiety disorders and the S allele and SS genotype of the 5-HTT gene. As expected, major depression was also found to be strongly associated with suicide risk, and suicide risk with anxiety disorders, and this association persisted in the multivariate analysis, from which suicide risk had to be excluded due to its high colinearity with anxiety disorders. This strong association between the 5-HTT S allele, anxiety disorders, major depressive disorder and the risk of suicide was found especially in individuals under 37 years with SS homozygotes or SL heterozygotes, similar to the findings of other authors (33). The literature also shows high rates of comorbidity between major depressive disorder and anxiety disorders. Some authors recognize anxiety as an axial symptom in major depression, and have found evidence of the relationship between the polymorphism evaluated in this study and anxious symptoms, the activity of the amygdala and the anxiety response (33-36). In addition, some authors have pointed out that the comorbid anxiety disorders of major depression increase implicit suicide risk (37).

Regarding the controversial results reported in the literature on the association of the 5-HTT gene in/ del polymorphism and major depression, it may be that sample size in some of the non-conclusive studies was very small and, thus, hindered their statistical power for finding significant differences between patients and controls, or they may have been affected by the selection of cases with very heterogeneous psychiatric phenotypes, a lack of adequate classification of cases and controls, the age of the compared groups, or the geographic origin, among other reasons $(20,21)$. With the increased number of studies of this polymorphism and the subsequent increase in sample size, a greater statistical significance has been registered for this association, especially in the meta-analyses that have been undertaken.

In this study's sample, the most frequent genotype was the SL heterozygote, which agrees with previous findings in the Colombian population.

The SL heterozygote polymorphism of the 5-HTT gene was found to be significantly associated with major depression, after adjusting for comorbid generalized anxiety disorders and anxiety disorder at least once in their lifetime. The severity of suicide risk was found to be very significantly associated with major depression, and was ultimately excluded from the multivariate model due to its high colinearity with generalized anxiety disorder. The $S$ allele of the 5-HTT gene, adjusting for the same variables, was borderline significant.

After adjusting for co-morbid anxiety disorders, a statistically significant association was found between the $S$ allele of the 5-HTT gene and major depressive disorder in individuals under the age of 37. It is likely that younger cases of major depressive disorder have a higher genetic influence that has made them more susceptible to the earliest form of the disorder; therefore, it is more likely to find these genetic associations in younger people. 
The factors associated with major depressive disorder were comorbidity with anxiety disorders (anxiety disorder at least once in their lifetime, and generalized anxiety disorder), suicide risk, and family history of depression. A familial tendency towards suicide was also found among cases.

This study evaluated the association between a single genetic polymorphism (5-HTT gene) and major depressive disorder. Given the polygenic nature of the major depressive disorder, new studies will be needed to evaluate multiple genetic characteristics.

Some associations showed a tendency towards a difference between the case and control groups, but the small sample size could have impeded a statistical significance level. The evaluated sample is not representative of the major depressive disorder cases in the city of Bogotá, nor do the controls represent the Bogotá's local population, and, therefore, results cannot be generalized. The sample was selected from the same population base and was homogeneous in terms of residence in Bogotá. Additionally, comparability between cases and controls and the validity of the statistical analysis is supported by the fact that no statistically significant differences between cases and controls were found in socio-demographic characteristics such as age, gender, education, socioeconomic level and marital status. It would be inferred that cases and controls differ as regards the presence or absence of the major depressive disorder and the factors closely related to the disorder.

It is also necessary to evaluate the triallelic model of the 5-HTT gene and the influence of polymorphisms of other genes involved in the susceptibility to major depressive disorder. Financial limitations prevented further assessment of other variants in 5-HTT gene, as well as the study of a larger sample of cases and controls. Subsequent studies are needed with larger samples that are representative of people with major depression in Bogotá and other regions of the country.

\section{Acknowledgments}

To the Psychiatric and Genetics Departments at Universidad del Rosario, particularly the geneticists Dora Fonseca and Jubby M. Gálvez, who typified the 5-HTT polymorphism, and to the psychiatrists who referred their patients to the study. To the patients and controls who, with their participation, made this study possible.

\section{Conflicts of interest}

There were no scientific, academic, or economic conflicts of interest.

\section{Funding}

This research was financed by Universidad del Rosario.

\section{References}

1. Andrade L, Caraveo-Anduaga JJ, Berglund P, Bijl RV, De Graaf R, Vollebergh W, et al. The epidemiology of major depressive episodes: Results from the International Consortium of Psychiatric Epidemiology (ICPE) Surveys. Int J Methods Psychiatr Res. 2003;12:3-21. http://dx.doi. org/10.1002/mpr.138

2. Ministerio de la Protección Social de Colombia. Estudio Nacional de Salud Mental, Colombia, 2003. Accessed: May 15, 2011. Available from: http://onsm.ces.edu.co/uploads/ files/1243030_EstudioNacionalSM2003.pdf.

3. Mathers CD, Loncar D. Updated projections of global mortality and burden of disease, 2002-2030: Data sources, methods and results, 2005. Accessed: September 24, 2012. Available from: http://www.who.int/healthinfo/statistics/ bodprojectionspaper.pdf.

4. World Health Organization WHO. The Global Burden of Disease: 2004 update. Accessed: June 10, 2012. Available from: http://www.who.int/healthinfo/global_burden_disease/ GBD_report_2004update_full.pdf.

5. Kessler RC, Greenberg PE, Mickelson KD, Meneades LM, Wang PS. The effects of chronic medical conditions on work loss and work cutback. J Occup Environ Med. 2001;43:218-25.

6. Punakallio A, Lusa S, Luukkonen R, Airila A, Leino-Arjas P. Musculoskeletal pain and depressive symptoms as predictors of trajectories in work ability among finnish firefighters at 13-year follow-up. J Occup Environ Med. 2014;56:367-75. http://dx.doi.org/10.1097/JOM.0000000000000139

7. Acosta N. Carga de enfermedad, Colombia, 2005: resultados alcanzados. Documento técnico ASS/1502-08. 2008. Accessed: February 10, 2011. Available from: https://www. minsalud.gov.co/sites/rid/Lists/BibliotecaDigital/RIDE/INEC/ UNIV/PresentacionCarga_Informe2005.pdf.

8. Ebmeier KP, Donaghey C, Steele JD. Recent developments and current controversies in depression. Lancet. 2006;367:153-67. http://dx.doi.org/10.1016/S0140-6736(06) 67964-6

9. Sullivan PF, Neale MC, Kendler KS. Genetic epidemiology of major depression: Review and meta-analysis. Am J Psychiatry. 2000;157:1552-62. http://dx.doi.org/10.1176/appi. ajp.157.10.1552

10. McGrath LM, Cornelis MC, Lee PH, Robinson EB, Duncan LE, Barnett JH, et al. Genetic predictors of risk and resilience in psychiatric disorders: A cross-disorder genomewide association study of functional impairment in major depressive disorder, bipolar disorder, and schizophrenia. Am J Med Genet B Neuropsychiatr Genet. 2013;162B:77988. http://dx.doi.org/10.1002/ajmg.b.32190

11. Levinson DF. The genetics of depression: A review. Biol Psychiatry. 2006;60:84-92. http://dx.doi.org/10.1016/j. biopsych.2005.08.024 
12. Kendler KS, Gardner CO, Neale MC, Prescott CA. Genetic risk factors for major depression in men and women: Similar or different heritabilities and same or partly distinct genes? Psychol Med. 2001;31:605-16.

13. Hariri AR, Holmes A. Genetics of emotional regulation: The role of the serotonin transporter in neural function. Trends Cogn Sci. 2006;10:182-91. http://dx.doi.org/10.1016/j.tics. 2006.02.011

14. Lesch KP, Bengel D, Heils A, Sabol SZ, Greenberg BD, Petri S, et al. Association of anxiety-related traits with a polymorphism in the serotonin transporter gene regulatory region. Science. 1996;274:1527-31. http://dx.doi. org/10.1126/science.274.5292.1527

15. Neumeister A, Young T, Stastny J. Implications of genetic research on the role of the serotonin in depression: Emphasis on the serotonin type $1 \mathrm{~A}$ receptor and the serotonin transporter. Psychopharmacology (Berl). 2004;174:512-24. http://dx.doi.org/10.1007/s00213-004-1950-3

16. Stockmeier CA. Involvement of serotonin in depression: Evidence from postmortem and imaging studies of serotonin receptors and the serotonin transporter. $J$ Psychiatr Res. 2003;37:357-73. http://dx.doi.org/10.1016/S0022-3956(03) 00050-5

17. Serretti A, Calati R, Mandelli L, De Ronchi D. Serotonin transporter gene variants and behavior: A comprehensive review. Curr Drug Targets. 2006;7:1659-69. http://dx.doi. org/10.2174/138945006779025419

18. Furlong RA, Ho L, Walsh C, Rubinsztein JS, Jain S, Paykel ES, et al. Analysis and meta-analysis of two serotonin transporter gene polymorphisms in bipolar and unipolar affective disorders. Am J Med Genet. 1998;81:58-63. http://dx.doi.org/10.1002/(SICI)1096-8628(19980207)81: 1<58::AID-AJMG11>3.0.CO;2-V

19. Haenisch B, Herms S, Mattheisen M, Steffens M, Breuer R, Strohmaier J, et al. Genome-wide association data provide further support for an association between 5-HTTLPR and major depressive disorder. J Affect Disord. 2013;146:43840. http://dx.doi.org/10.1016/j.jad.2012.08.001.

20. Anguelova M, Benkelfat C, Turecki G. A systematic review of association studies investigating genes coding for serotonin receptors and the serotonin transporter: I. Affective disorders. Mol Psychiatry. 2003;8:574-91. http:// dx.doi.org/10.1038/sj.mp.4001328

21. López-León S, Janssens AC, González-Zuloeta Ladd AM, Del-Favero J, Claes SJ, Oostra BA, et al. Metaanalyses of genetic studies on major depressive disorder. Mol Psychiatry. 2008;13:772-85. http://dx.doi.org/10.1038/ sj.mp.4002088

22. Anguelova M, Benkelfat C, Turecki G. A systematic review of association studies investigating genes coding for serotonin receptors and the serotonin transporter: II. Suicidal behavior. Mol Psychiatry. 2003;8:646-53. http://dx. doi.org/10.1038/sj.mp.4001336

23. Lasky-Su JA, Faraone SV, Glatt SJ, Tsuang MT. Metaanalysis of the association between two polymorphisms in the serotonin transporter gene and affective disorders. Am J Med Genet B Neuropsychiatr Genet. 2005;133B:110-5. http://dx.doi.org/10.1002/ajmg.b.30104

24. Hoehe MR, Wendel B, Grunewald I, Chiaroni P, Levy N, Morris-Rosendahl D, et al. Serotonin transporter (5-HTT) gene polymorphisms are not associated with susceptibility to mood disorders. Am J Med Genet. 1998;81:1-3. http://dx.
doi.org/10.1002/(SICI)1096-8628(19980207)81:1<1::AIDAJMG1>3.0.CO;2-2

25. Minov C, Baghai TC, Schüle C, Zwanzger P, Schwarz MJ, Zill P, et al. Serotonin-2A-receptor and -transporter polymorphisms: Lack of association in patients with major depression. Neurosci Lett. 2001;303:119-22. http://dx.doi. org/10.1016/S0304-3940(01)01704-9

26. Mendlewicz J, Massat I, Souery D, Del-Favero J, Oruc L, Nöthen MM, et al. Serotonin transporter 5HTTLPR polymorphism and affective disorders: No evidence of association in a large European multicenter study. Eur $\mathrm{J}$ Hum Genet. 2004;12:377-82. http://dx.doi.org/10.1038/sj. ejhg.5201149

27. Serretti A, Lilli R, Lorenzi C, Lattuada E, Cusin C, Smeraldi E. Serotonin transporter gene (5-HTTLPR) and major psychoses. Mol Psychiatry. 2002;7:95-9. http://dx.doi. org $/ 10.1038 / \mathrm{sj} / \mathrm{mp} / 4000936$

28. Ospina-Duque J, Duque C, Carvajal-Carmona L, OrtízBarrientos D, Soto I, Pineda N, et al. An association study of bipolar mood disorder (type I) with the 5-HTTLPR serotonin transporter polymorphism in a human population isolate from Colombia. Neurosci Lett. 2000;292:199-202. http://dx.doi.org/10.1016/S0304-3940(00)01464-6

29. Rengifo L, Gaviria D, Salazar L, Vélez JP, Lozano S. Polimorfismos en el gen del transportador de serotonina (SLC6A4) y el trastorno afectivo bipolar en dos centros regionales de salud mental del Eje Cafetero. Revista Colombiana de Psiquiatría. 2012;41:86-100.

30. Escobar CG, Calderón JH, Moreno GA. Allelic polymorphism in the serotonin transporter gene in major depression patients. Colombia Médica. 2011;42:48-53.

31. Akhtar-Danesh N, Landeen J. Relation between depression and sociodemographic factors. Int $\mathrm{J}$ Ment Health Syst. 2007;1:4. http://dx.doi.org/10.1186/1752-4458-1-4

32. Ho LW, Furlong RA, Rubinsztein JS, Walsh C, Paykel ES, Rubinsztein DC. Genetic associations with clinical characteristics in bipolar affective disorder and recurrent unipolar depressive disorder. Am J Med Genet. 2000;96: 36-42. http://dx.doi.org/10.1002/(SICI)1096-8628(20000207) 96:1<36::AID-AJMG8>3.0.CO;2-6

33. Pfeiffer PN, Ganoczy D, Ilgen M, Zivin K, Valenstein M. Comorbid anxiety as a suicide risk factor among depressed veterans. Depress Anxiety. 2009;26:752-7. http://dx.doi. org/10.1002/da.20583

34. Hirschfeld RM. The comorbidity of major depression and anxiety disorders: Recognition and management in primary care. Prim Care Companion J Clin Psychiatry. 2001;3:244-54.

35. Lau JY, Goldman D, Buzas B, Fromm SJ, Guyer AE, Hodgkinson C, et al. Amygdala function and 5-HTT gene variants in adolescent anxiety and major depressive disorder. Biol Psychiatry. 2009;65:349-55. http://dx.doi. org/10.1016/j.biopsych.2008.08.037

36. Ressler KJ, Nemeroff CB. Role of serotonergic and noradrenergic systems in the pathophysiology of depression and anxiety disorders. Depress Anxiety. 2000;12(Suppl.1):219. http://dx.doi.org/10.1002/1520-6394(2000)12:1+<2::AIDDA2>3.0.CO;2-4

37. Murphy SE, Norbury R, Godlewska BR, Cowen PJ, Mannie ZM, Harmer CJ, et al. The effect of the serotonin transporter polymorphism (5-HTTLPR) on amygdala function: A meta-analysis. Mol Psychiatry. 2013;18:512-20. http://dx.doi.org/10.1038/mp.2012.19 